\title{
KEBIJAKAN RESPONSIF SEBAGAI INSTRUMEN TRANSFORMASI PELAYANAN PUBLIK PADA MASA PANDEMI COVID-19
}

\author{
Eny Haryati $^{1 *}$, Dian Ferriswara ${ }^{2}$ \\ ${ }^{1,2}$ Universitas Dr. Soetomo Surabaya \\ *eny.haryati@unitomo.ac.id
}

\begin{abstract}
Abstrak
Belakangan ini pandemi Corona Virus Disease (yang popular dengan Covid-19) menjadi salah satu variabel utama yang menyebabkan terjadinya perubahan sosial maupun perubahan tata kehidupan bermasyarakat dan bernegara, tidak saja di Indonesia, tetapi bahkan juga di dunia. Perubahan tersebut terjadi di hampir semua sektor, tidak terkecuali pada sektor pelayanan publik. Sejumlah kebutuhan publik terhadap pelayanan publik mengalami perubahan sangat mendasar. Hal ini memerlukan respon dari pihak penyelenggara pelayanan publik, berupa inovasi pelayanan yang sesuai dengan bentuk, jenis, dan sifat kebutuhan publik yang telah mengalami berubahan tersebut. Ketika suatu lembaga penyelenggara pelayanan publik menjadi bagian dari struktur pemerintah dan/atau pemerintah daerah, maka diperlukan suatu kebijakan publik yang memayungi inovasi yang diciptakan. Berdasarkan penelitian yang peneliti lakukan terhadap pelayanan perpajakan pada Unit Pelayanan Teknis Pengelola Pendapatan Daerah (UPT-PPD) Malang Selatan, Kabupaten Malang Provinsi Jawa Timur, menunjukkan bahwa: (1) pada masa pandemi ini telah terjadi perubahan kebutuhan publik terhadap jenis pelayanan publik terutama pelayanan pembayaran pajak kendaraan bermotor; (2) para petugas penyelenggara pelayanan publik memerlukan sejumah cara baru dan sumberdaya pendukung guna merespon perubahan kebutuhan publik tersebut; (3) untuk menjaga dan meningkatkan efektifitas pelayanan publik di masa pandemi Covid-19, telah diciptakan inovasi pelayanan dengan nomenklatur "Jelajah Lintas Desa" (Jelita); (4) temuan tersebut menguatkan teori Bromley (1989) tentang Hierarchy of Policy Formulation; dan sejalan dengan asumsi teori Bromley ini pula peneliti merekomendasikan agar Pemerintah Daerah merespon fenomena tersebut dengan mengambil kebijakan yang responsif, didahuli dengan melakukan analisis kebutuhan (assessment) dan menetapkan kebijakan pada tingkat operasional yang kemudian ditindaklanjuti dengan merumuskan standar operasional prosedur (yang dalam teori Bromley disebut sebagai "instutional arrangements"); agar dapat memayungi inovasi pelayanan yang telah dilakukan oleh penyelenggara pelayanan publik, sekaligus dapat menjadi instrumen dalam rangka melakukan transformasi pelayanan publik guna menjaga dan meningkatkan kualitas pelayanan publik di masa pandemi Covid-19 ini.
\end{abstract}

Kata Kunci : transformasi, pelayanan publik, kebijakan responsif, pandemi covid-19.

Abstract

Recently the Corona Virus pandemic (which is popular with Covid-19) has become one of the main variables causing social change and changes in the order of life in society and the state, not only in Indonesia but also in the world. This change occurred in almost all sectors, including the public service sector. A number of public needs for public services have undergone very basic changes. For this reason, a response from public service providers is needed in the form of service innovations that are in accordance with the form, type, and nature of the needs of the community that have undergone these changes. If a public service provider institution becomes part of the government and/or regional government structure, it requires a public policy containing innovation. Based on research conducted by researchers regarding tax services at the Regional Revenue Management Technical Service Unit (UPT-PPD), Malang Regency, East Java Province shows that: (1) During this pandemic there has been a change in people's needs for types of public services, particularly motor vehicle tax payment services; (2) public service providers need new methods and support resources to respond to these changing public needs; (3) to maintain and improve the effectiveness of public services during the Covid-19 pandemic, service innovations have been created with the nomenclature "Jelajah Lintas Desa" (Jelita); (4) these findings corroborate Bromley's (1989) theory of the Policy Formulation Hierarchy; and in line with Bromley's theoretical assumptions, the researcher also recommends that local governments respond to this phenomenon by taking responsive policies, starting with a needs analysis (assessment) and establishing policies at the operational level which are then followed up by standard-setting operating procedures (what Bromley called "institutional arrangements"); to be able to include service innovations that have been carried out by public service 
Seminar Nasional Penelitian dan Pengabdian kepada Masyarakat Universitas Sang Bumi Ruwa Jurai Tahun 2020

providers, as well as being an instrument in the framework of transforming public services to maintain and improve the quality of public services during the Covid-19 pandemic.

Keywords: transformation, public services, responsive policies, the Covid-19 pandemic.

\section{PENDAHULUAN}

Dunia saat ini sedang diguncang oleh muncul dan berkembangnya virus Corona yang kemudian menyebabkan terjadinya pandemi Corona Virus Disease (Covid-19). Pandemi ini membawa dampak signifikan terhadap perubahan kehidupan bermasyaraat dan bernegaraa, tidak saja pada tingkat nasional di Indonesia, akan tetapi juga pada tingkat dunia. Mulai dari keadaan makro pada sektor kehidupan ekonomi, sosial-budaya, dan lain-lain sampai dengan keadaan mikro pada sektor-sektor kehidupan sehari-hari masyarakat, hampir dapat dipastikan tidak ada yang bisa terhindar dari dampak pandemi Covid-19 ini; tidak terkecuali sektor pelayanan publik (Andhika, 2020). Pendek kata, pandemi Covid-19 tercatat sebagai suatu realitas sosial yang memiliki implikasi luas, bukan hanya di sektor kesehatan yang diukur dari besarnya jumlah korban yang terinfeksi dan yang meninggal dunia, namun juga luasnya dampak negatif yang ditimbulkannya (Haryati, 2020). Pada konteks ini penyelenggaraan pelayanan publik menjadi salah satu kegiatan yang sangat terguncang oleh pandemi Covid-19. Sebagai contoh, dengan adanya Surat Edaran yang dikeluarkan oleh Menteri Pendayagunaan Aparatur Negara dan Reformasi Birokrasi Nomor 19 Tahun 2020 tentang Penyesuaian Sistem Kerja Aparatur Sipil Negara Dalam Upaya Pencegahan Penyebaran Covid-19 Di Lingkungan Instasi Pemerintah (Menteri Pendayagunaan Aparatur Negara dan Reformasi Birokrasi Republik Indonesia, 2020); dimana Surat Edaran ini memberlakukan work from home (WFH) yaitu bekerja dari rumah secara bergantian bagi para pegawai di lingkungan instansi pemerintah; telah menyebabkan pelayanan publik menjadi terhambat, sebab beberapa lembaga penyelenggara pelayanan publik tidak dapat melayani masyarakat secara langsung sehingga penyelenggaraan pelayanan publik (pemenuhan kebutuhan publik) tidak dapat dilakukan secara optimal.

Guna merespon kondisi pandemi Covid-19 dan dalam rangka menekan penyebaran virus Corona-19, pada tanggal 31 Maret 2020 pemerintah menerbitkan Peraturan Pemerintah Republik Indonesia Nomor 21 Tahun 2020 tentang Pembatasan Sosial Berskala Besar Dalam Rangka Percepatan Penanganan Covid-19 (Pemerintah Republik Indonesia, 2020). Implikasi atas pemberlakuan Peraturan Pemerintah ini amat luas; bebeberapa wilayah di tanah air memberlakukan Pembatasan Sosial Berskala Besar (PSBB) yang menyebabkan lembaga pendidikan dan tempat kerja diliburkan, kegiatan keagamaan atau ibadah bersama dibatasi dan kegiatan-kegiatan di tempat umum atau fasilitas publik juga dibatasi. Hal ini bertujuan untuk menghindari terjadinya kerumunan banyak orang pada suatu tempat, membatasi interaksi dengan orang lain, mengurangi transaksi dengan uang secara fisik dan lain-lain; agar risiko penularan virus Corona-19 dapat ditekan, sesuai dengan substansi protokol kesehatan yang diberlakukan di masa pandemi Covid-19.

Pemberlakuan PSBB membawa dampak besar pada aksesibilitas pelayanan publik sekaligus menciptakan suatu dilema baik bagi penyelenggara pelayanan publik maupun bagi pengguna pelayanan publik. Di satu sisi penyelenggara pelayanan yang biasanya melakukan pelayanan secara konvensional yakni dengan bertatap muka secara langsung di suatu tempat, pada masa pandemi Covid-19 ini mengambil langkah melakukan pembatasan jumlah pelayanan pada tiap-tiap harinya. Pada sisi yang lain publik yang biasanya menjadi pengguna pelayaan, juga 
memiliki perasaan ragu/takut untuk mengunjungi tempat-tempat penyelenggaraan pelayanan publik, meskipun mereka memerlukan pelayanan itu. Dilema ini menjadi titik awal sekaligus sinyal bahwa sesungguhnya kebutuhan publik akan bentuk dan jenis serta sifat pelayanan publik telah mengalami perubahan.

Perubahan kondisi sosial masyarakat serta perubahan kebutuhan publik tampaknya tidak boleh diabaikan; artinya bahwa perubahan tersebut perlu mendapat respon dan perlu diakomodasi menjadi salah satu masukan bagi para penyelenggara pelayanan publik dan para penentu kebijakan. Perubahan kebutuhan publik, disamping disebabkan oleh terjadinya pandemi Covid19, juga disebabkan oleh kemajuan teknologi komunikasi. Kondisi semacam ini dalam pandangan Anderson (1979) mengharuskan para pembuat kebijakan untuk mau dan mampu bersikap responsif dan adaptif, baik terhadap bentuk dan jenis kebutuhan publik yang telah mengalami perubahan akibat suatu mondisi sosial tertentu maupun responsif dan adaptif terhadap perubahan kebutuhan publik sebagai akibat dari perkembangan teknologi yang sedang terjadi. Meskipun harus diakui bahwa salah satu kendalanya adalah bahwa secara umum pembahasan suatu permasalahan menuju perumusan suatu kebijakan yang responsive dan adaptif tersebur membutuhkan waktu yang lama, baik pada saat identifikasi masalah serta pada saat menyusun alternatif solusinya serta pada saat proses formulasi dan pembahasan rancangan kebijakan (Mulyani, 2019).

Pada masa pandemi Covid-19 yang ditandai dengan berubahnya kebutuhan publik ini, tampaknya para penyelenggara pelayanan publik dipandang perlu menciptakan inovasi-inovasi dalam memberikan pelayanan agar palayanan tidak terhambat. Menyikapi kondisi yang demikian ini, Rachel Silcock (Silcock, 2001 dikutip Lumbanraja, 2020) menyarankan agar para penyelenggara pelayanan publik meresponnya dengan melahirkan kebijakan yang responsif terhadap perubahan kebutuhan publik dengan cara melakukan inovasi yang berbasis teknologi $(e-$ government), adalah penggunaan teknologi untuk meningkatkan akses dan pengiriman layanan pemerintah untuk memberi manfaat bagi warga negara, mitra bisnis, dan karyawan. Selain penggunaan teknologi juga diperlukan sikap responsif-inovatif untuk melakukan pengembangan model pelayanan publik baru di mana suatu lembaga penyelenggara pelayanan publik dapat memberikan pelayanan yang modern, terintegrasi, dan sesuai dengan kebutuhan publik yang dilayani.

Berhubungan dengan konteks pencapian tujuan suatu kebijakan dan pemecahan masalah publik, Anderson (1979) menerangkan bahwa kebijakan publik merupakan serangkaian kegiatan yang mempunyai maksud atau tujuan tertentu yang diikuti dan dilaksanakan oleh seorang aktor atau sekelompok aktor yang berhubungan dengan suatu permasalahan atau suatu hal yang diperhatikan.

Berdasarkan teori yang dikemukakan Bromley dalam Tachjan (2006), kebijakan publik memiliki tiga tingkatan yang berbeda berdasarkan hierarki kebijakan, yaitu: policy level, organizational level, operational level. Dalam suatu negara demokratis policy level diperankan oleh lembaga yudikatif dan legislatif, sedang organizational level diperankan oleh lembaga eksekutif. Selanjutnya operational level dilaksanakan oleh satuan pelaksana seperti kedinasan, kelembagaan atau kementerian. Pada masing-masing level, kebijakan publik diwujudkan dalam bentuk institutional arrangement atau peraturan perundangan yang disesuaikan dengan tingkat hierarkinya. Sementara pattern interaction adalah pola interaksi antara pelaksana kebijakan paling bawah (street level bureaucrat) dengan kelompok sasaran (target group) kebijakan yang menunjukkan pola pelaksanaan kebijakan yang menentukan dampak (outcome) dari kebijakan tersebut. Hasil suatu kebijakan dalam kurun waktu tertentu yang ditetapkan akan ditinjau kembali 
Seminar Nasional Penelitian dan Pengabdian kepada Masyarakat Universitas Sang Bumi Ruwa Jurai Tahun 2020

(assesment) untuk menjadi umpan balik (feedback) bagi semua level kebijakan yang diharapkan terjadi sebuah perbaikkan atau peningkatan kebijakan.

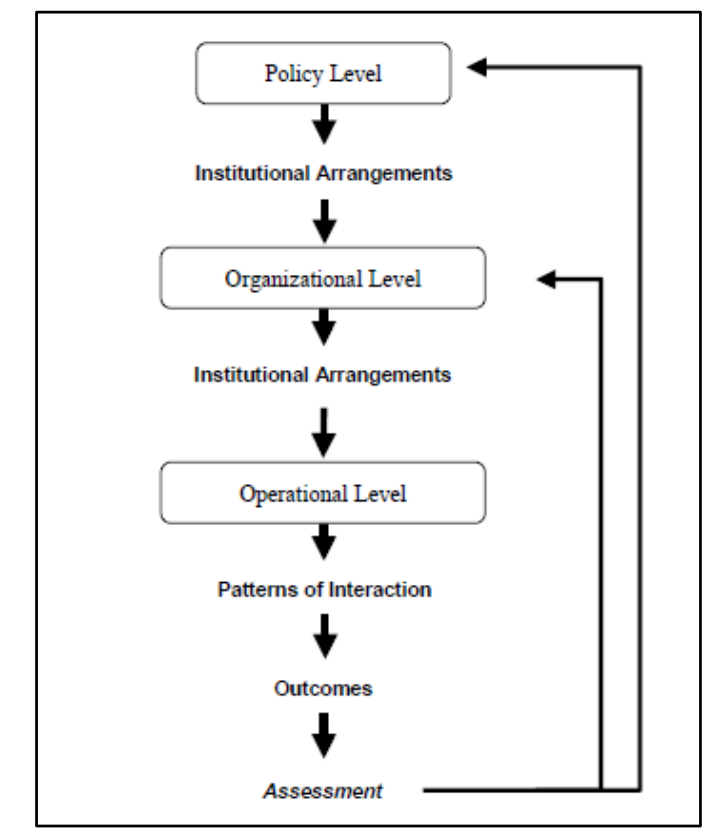

Gambar 1. Hirarky Kebijakan Model Bromley (1989)

Berangkat dari penjelasan sebagaimana diuraikan di atas, maka dipandang perlu melakukan penelitian ini, dengan judul "Kebijakan Responsif Sebagai Instrumen Transformasi Pelayanan Publik Pada Masa Pandemi Covid-19", studi terhadap pelayanan pajak kendaraan bermotor pada Unit Pelayanan Teknis Pengelola Pendapatan Daerah (UPT-PPD) Malang Selatan,

Penelitian ini bersandar pada tiga konsep, dan inilah yang membedakan dengan sejumlah penelitian terdahulu yang dilakukan oleh (1) Juaningsih, Consuello, Tarmidzi, \& NurIrfan (2020) berjudul Optimalisasi Kebijakan Pemerintah dalam penanganan Covid-19 terhadap Masyarakat Indonesia; (2) Lumbanraja (2020) berjudul Urgensi Transformasi Pelayanan Publik melalui EGovernment Pada New Normal dan Reformasi Regulasi Birokrasi.

Tiga konsep yang dijadikan sandaran penelitian ini, meliputi: (1) memperhatikan dan merespon pemberlakuan protokol kesehatan dan perubahan tata kehidupan masyarakat di masa pandemi Covid-19; (2) merespon perkembangan teknologi; (3) memperhatikan hirarki kebijakan yang berlaku.

Penelitian ini memfokuskan pada masalah: "Bagaimanakah respon UPT-PPD Malang Selatan dalam rangka melakukan transformasi pelayanan publik di masa pandemi Covid-19?; untuk selanjutnya penelitian ini betujuan: (1) mendeskripsikan program/kebijakan responsifinovatif dalam rangka melakukan transformasi pelayanan publik di masa pandemi Covid-19; (2) mendeskripsikan faktor pendukung program/kebijakan responsif-inovatif yang diciptakan; (3) hasil yang dicapai atas implementasi program/kebijakan responsif-inovatif tersebut; (4) hal-hal apa yang diperlukan agar implementasi program/kebijakan responsif-inovatifnya dapat menjadi 
instrumen dalam melakukan transformasi pelayanan publik guna meningkatkan kepuasan masyarakat.

\section{METODE PENELITIAN}

Lokasi penelitian ini adalah Unit Pelayanan Teknis Pengelola Pendapatan Daerah (UPTPPD) Malang Selatan yang memiliki tugas pokok dan fungsi utama sebagai penyelenggara pelayanan pembayaran pajak kendaraan bermotor (PKB) dan biaya balik nama kendaraan bermotor (BBNKB). Penelitian merupakan penelitian deskriptif (Hidayat, 2010), yang menjelaskan program/kebijakan yang diciptakan oleh UPT-PPD Malang Selatan dalam merespon perubahan kebutuhan publik di masa pandemi Covid-19; dengan pendekatan kualitatif (Miles \& Huberman, 1992) penelitian ini menjelaskan bagaimanakaah respon UPT-PPD Malang Selatan dalam rangka melakukan transformasi pelayanan publik di masa pandemi Covid-19.

Terdapat tiga metode pengumpulan data yang digunakan, meliputi: (1) wawancara, meliputi wawancara mendalam dengan seorang informan kunci, wawancara dengan dua orang petugas pelayanan, dan wawancara dengan 12 orang wajib pajak; (2) observasi dengan melihat secara langsung pelaksanaan inovasi pelayanan; (3) studi dokumen dengan mengkaji sejumlah dokumen yang dimiliki UPT-PPD Malang Selatan, khususnya dokumen yang terkait dengan penelitian ini. Data hasil wawancara yang peneliti lakukan dengan para wajib pajak merupakan data yang peneliti jadikan sebagai bahan melakukan triangulasi.

Teknik analisis kualitatif model interaktif (Miles \& Huberman, 1992), yang terdiri atas reduksi data, penyajian data, menarik kesimpulan dan verifikasi; menjadi teknik analisis yang digunakan dalam menganalisis program/kebijakan responsive-inovatif yang diciptakan oleh UPTPPD Malang Selatan dalam rangka melakukan transformasi pelayanan publik di masa pandemi Covid-19

\section{HASIL DAN PEMBAHASAN}

\section{Tugas Pokok dan Fungsi UPT-PPD}

Unit Pelayanan Teknis Pengelola Pendapatan Daerah (UPT-PPD) Malang Selatan ini merupakan salah satu UPT-PPD dari 35 UPT-PPD yang berada di bawah struktur kelembagaan Badan Pendapatan Daerah Provinsi Jawa Timur. Tugas pokok dan fungsi UPT-PPD ini diatur dalam Peraturan Gubernur Jawa Timur Nomor 47 Tahun 2018 Tentang Nomenklatur, Susunan Organisasi, Uraian Tugas Dan Fungsi Serta Tata Kerja Unit Pelaksana Teknis Badan Pendapatan Daerah Provinsi Jawa Timur (Gubernur Jawa Timur Republik Indonesia, 2018). UPT-PPD mempunyai tugas melaksanakan sebagian tugas Badan Pendapatan Daerah di bidang teknis operasional pemungutan pendapatan daerah, ketatausahaan serta pelayanan masyarakat. Adapun ntuk melaksanakan tugas tersebut, UPT-PPD mempunyai fungsi: (1) penyusunan perencanaan program dan kegiatan teknis UPT; (2) pelaksanaan kegiatan teknis operasional pemungutan Pendapatan Asli Daerah; (3) pelaksanaan pemungutan Pajak Kendaraan Bermotor (PKB) dan Bea Balik Nama Kendaraan Bermotor (BBNKB) pada Kantor Bersama Samsat; (4) pelaksanaan koordinasi dengan instansi terkait pada Kantor Bersama Samsat; (5) pelaksanaan koordinasi dengan Pemerintah Daerah Kabupaten/Kota terkait dengan pemungutan Pendapatan Asli Daerah; (7) pelaksanaan tugas-tugas ketatausahaan dan pelayanan masyarakat; (8) pelaksanaan monitoring 
Seminar Nasional Penelitian dan Pengabdian kepada Masyarakat Universitas Sang Bumi Ruwa Jurai Tahun 2020

dan evaluasi pelaksanaan program dan kegiatan UPT; dan (9) pelaksanaan tugas-tugas lain yang diberikan oleh Kepala Badan.

\section{Kontribusi Pendapatan Daerah Terhadap APBD Jawa Timur}

UPT-PPD sebagai pelaksana pelayanan pembayaran pajak oleh masyarakat, memegang peran yang sangat penting dalam struktur kelembagaan Badan Pendapatan Daerah Provinsi Jawa Timur. Ini karena pendapatan daerah Adapun dari total Anggaran Pendapatan dan Belanja Daerah (APBD) tahun 2019 yang sebelumnya Rp 33,519 triliun dan kemudian ditingkatka menjadi sebesar Rp 37,985 triliun itu, yang Rp. 19,721 triliun masuk melalui pintu Badan Pendapatan Daerah, yang digawangi oleh 35 buah UPT-PPD se Jawa Timur. Ini berarti bahwa 51,91\% dari APBD Provinsi Jawa Timur dikontribusi oleh pendapatan daerah yang masuk melalui pintu UPT-PPD (Badan Pendapatan Daerah Proinsi Jawa Timur, Data Sekunder, 2019).

Tabel 1. Penerimaan Pajak 2019 Provinsi Jawa Timur

\begin{tabular}{clccc}
\hline No & \multicolumn{1}{c}{ Jenis Pajak } & \multicolumn{1}{c}{ Target } & \multicolumn{1}{c}{ Realisasi } & \% berdasarkan target \\
\hline 1 & $\begin{array}{l}\text { Pajak Kendaraan Bermotor } \\
\text { (PKB) }\end{array}$ & Rp. 6.350.000.000.000 & Rp. 6.890.439.193.872 & $108,51 \%$. \\
2 & $\begin{array}{l}\text { Bea Balik Nama Kendaraan } \\
\text { Bermotor (BBNKB) }\end{array}$ & Rp. 3.750.000.000.000 & Rp. 4.232 .540 .305 .900 & $112,72 \%$. \\
3 & $\begin{array}{l}\text { Pajak Bahan Bakar } \\
\text { Kendaraan Bermotor }\end{array}$ & Rp. 2.400.000.000.000 & Rp. 2.374.099.329.438 & 99,75\%, \\
& & & \\
4 & PBBKB) & Rajak Air Permukaan (PAP) 3.862 .000 .000 .000 & Rp. 4.232.540.305.900 & $109,6 \%$ \\
5 & $\begin{array}{l}\text { Pajak Rokok } \\
\text { Jumlah }\end{array}$ & Rp. 2.190.000.000.000 & Rp. 1.992 .207 .318 .173 & $83,78 \%$. \\
\hline
\end{tabular}

Sumber: Badan Pendapatan Daerah Provinsi Jawa Timur, Data Sekunder, 2019

Berdasarkan dokumen yang diserahkan Pemerintah Provinsi Jawa Timur kepada DPRD melalui Rapat Paripurna DPRD, Rabu tanggal 19 Agustur 2020, terdapat koreksi anggaran. Dari total APBD 2020 sebesar Rp35,1 triliun, realisasi anggarannya ditargetkan hanya sebesa Rp33,14 triliun atau sekitar Rp1,9 triliun. Dari jumlah tersebut ditargetkan sebesar Rp12,3 triliun diperoleh dari pendapatan asli daerah $(37,11 \%)$.

\section{Permasalahan UPT-PPD di Masa Pandemi}

Hasil wawancara dengan informan kunci (Kepala UPT-PPD) Malang Selatan menunjukkan bahwa pada masa pandemi Covid-19 pembayaran pajak melalui Pintu UPT-PPD Kabupaten Malang mengalami penurunan sekitar 305 dibandingkan bulan yang sama pada tahun 2019. Hal ini dapat dipahami, mengingat di Jawa Timur diberlakukan protokol kesehatan yang sangat ketat serta diberlakaukannya Pembatasan Sosial Berskala Besar (PSBB) dalam kurun waktu 2x14 hari; serta menyikapi peningkatan secara drastis jumlah pasien yang dinyatakan positif terpapar virus Corona-19 di Jawa Timur, termasuk di wilayah Kabupaten Malang, khususnya Malang Selatan.

Sekurang-kurangnya terdapat lima permasalahan yang menyebabkan turunnya penerimaan pajaka sampai dengan triwulan kedua tahun 2020 yang dihadapi oleh UPT-PPD Malang Selatan di masa pandemi Covid-19, meliputi: (1) diberlakukannya work from home (WFH), yang membuat para pegawai tidak bekerja penuh; (2) keharusan untuk melaksanakan protokol kesehatan di tempat 
pelayanan publik (termasuk di UPT-PPD) membuat secara psikologis timbul rasa cemas dan mengalami keterbatasan cara berkomunikasi, baik yang dialami oleh pegawai (sebagai petugas pelayanan publik) maupun oleh publik (sebagai wajib pajak); (3) pada masa pandemi Covid-19 masyarakat secara umum (termasuk wajib pajak) mengalami penurunan penghasilan yang membuat secara ekonomi terjadi penurunan daya beli atau daya bayar.; (4) para wajib pajak yang berdomisili di wilayah terpencil dan/atau berjarak relatif jauh dari kantor UPT-PPD maupun dari unit-unit pos pelayanan pembayaran pajak, mengalami kesulitan untuk meelakukan pembayaran pajak karena terkendala oleh rasa cemas atau takut untuk menggunakan jasa transportasi umum. (5) belum semua wajib pajak dapat meng-akes fasilitas pelayanan pembayaran pajak online yang disediakan oleh UPT-PPD.

Permasalahan tersebut, apapun alasannya, merepresentasikan kinerja UPT-PPD Malang Selatan sebagai agen pelayanan publik di bidang pelayanan pembayaran pajak. Dua fenomena yang perlu mendapatkan perhatian dalam hal ini adalah: (1) telah terjadi perubahan jenis, bentuk dan sifat kebutuhan masyarakat akan pelayanan publik yang harus diberikan oleh UPT-PPD; (1) belum adanya regulasi yang mengatur tentang bentuk, jenis dan sifat pelayanan publik baru yang sesuai dengan perubahan kebutuhan publik.

\section{Inovasi Pelayanan (Wujud Responsibilitas UP-PPD)}

Program Jelajah Lintas Desa (JELITA) merupakan inovasi pelayanan pada UPT-PPD Malang Selatan yang diharapkan dapat menjawab permasalahan perubahan kebutuhan publik di masa pandemi Covid-19. Permasalahan dimaksud, berawal dari meluasnya Covid-19, menyusul diberlakukannya protokol kesehatan, yang substansinya sebagai berikut:

1. Perkantoran dan perusahaan diwajibkan membatasi jarak pekerjanya, termasuk meja kerja dan tempat duduk minimal 1 meter.

2. Memberikan tanda khusus yang ditempatkan di lantai area pekerja seperti ruang ganti, lift, dan area lain sebagai pembatas jarak antar pekerja.

3. Pengaturan jumlah pekerja yang masuk agar memudahkan penerapan menjaga jarak.

4. Lokasi tempat kerja juga harus bersih dan higienis dengan melakukan pembersihan berkala dengan pembersih dan disinfektan yang sesuai selama 4 jam sekali, terutama pegangan pintu dan tangga, tombol lift, peralatan bersama, area dan fasilitas umum.

5. Pekerja dan perusahaan harus menjaga kualitas udara tempat kerja, menyediakan sarana cuci tangan, menyediakan penyanitasi tangan dengan kandungan alkohol minimal 70 persen di tempat-tempat yang diperlukan

6. Selalu jaga kebersihan tangan. Bersihkan tangan dengan hand sanitizer atau menggunakan sabun dan air mengalir selama 20 detik. Cara mencucinya pun harus sesuai dengan standar yang ada, yaitu meliputi bagian dalam, punggung, sela-sela, dan ujung-ujung jari.

7. Hindari menyentuh area wajah, khususnya mata, hidung, dan mulut yang menjadi jalan masuk bagi penularan virus.

8. Terapkan etika batuk dan bersin. Dengan cara tutup mulut dan hidung menggunakan lengan atas bagian dalam. Bisa juga menutup mulut dan hidung menggunakan kain tisu yang setelahnya harus langsung dibuang ke tempat sampah.

9. Pakai masker. Jika menggunakan masker medis, maka hanya bisa digunakan 1 kali dan harus segera diganti. Buang masker medis di tempat sampah yang tertutup dan cuci tangan setelahnya. Bagi yang mengguakan masker kain, jangan lupa untuk rutin mencucinya.

10. Jaga kesehatan dengan konsumsi makanan bergizi, istirahat yang cukup dan rajin berolahraga, agar imun tubuh tetap terjaga. 
11. Isolasi mandiri di rumah bagi yang merasa tidak sehat, dan jangan memaksakan mendatangi tempat kerja, atau tempat umum lainnya.

Adapun wujud program Jelajah Lintas Desa (JELITA) ini, adalah: (1) petugas pelayanan mendatangi desa-desa, dengan prioritas pada desa yang terpencil atau yang jaraknya jauh dari kantor UPT-PPD; (2) sarana dan prasarana yang dibawa: 2 unit motor yang lengkap dengan vasilitas yang diperlukan, seperti : jaringan wifi, computer, printer dengan segala perangkat yang diperlukan; (3) ditugaskan 2 orang petugas pelayanan ke lokasi program JELITA.

Konsep yang dikembangkan dalam program Jelita adalah: (1) menjemput pelanggan atau mendekatkan pelayanan ke tempat domisili pelanggan/pengguna pelayanan; (2) menghindari terjadinya kerumunan (sesuai dengan protokol kesehatan); (3) menciptakan efisiensi bagi pelanggan baik efisiensi dari segi biaya transportasi, waktu perjalanan maupun tenaga; (4) menjalin hubungan informal silaturahim antara petugas penyelenggara pelayanan dengan pelanggan sebagai pengguna pelayanan; (5) petugas yang terjun ke desa-desa dalam program JELITA ini juga melakukan komunikasi-informasi-edukasi kepada publik sedemikian rupa agar mereka termotivasi untuk dapat melakukan pembayaran pajak secara tepat waktu; (6) petugas program JELITA juga melakukan komunikasi konsultatif dengan pihak pelanggan (waib pajak), guna mendapatkan masukan dan saran untuk bahan pengambilan kebijakan penyempurnaan kualitas pelayanan publik bagi UPT-PPD di masa pandemi ini. Gambar berikut ini melukiskan skema Inovasi Pelayanan Publik pada UPT=PPD Malang Selatan dengan nomenklatur program Jelajah Lintas Desa (JELITA). 
Seminar Nasional Penelitian dan Pengabdian kepada Masyarakat Universitas Sang Bumi Ruwa Jurai Tahun 2020

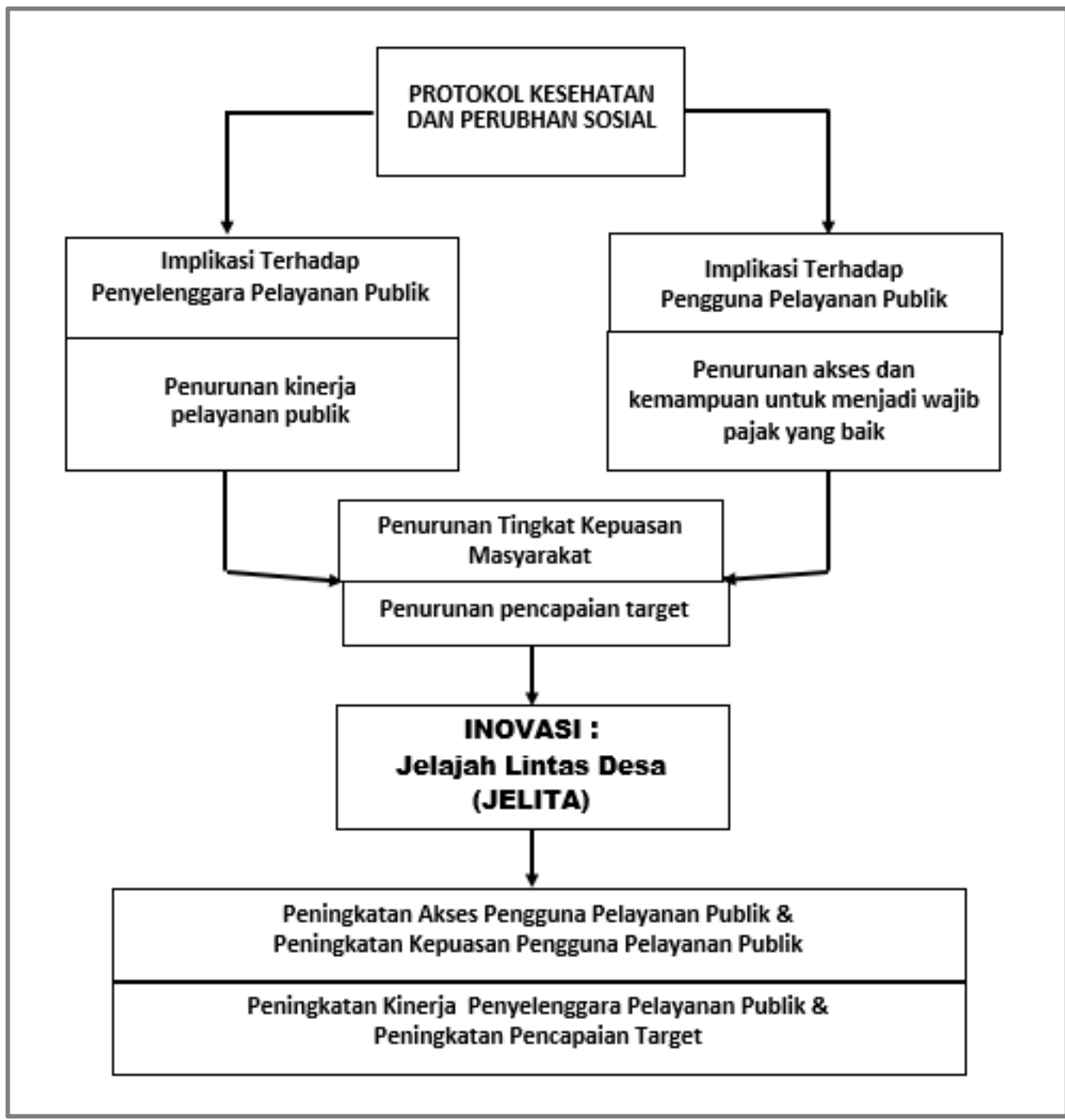

Gambar 2. Bagan Inovasi Pelayanan Publik pada UPT-PPD Malang Selatan 

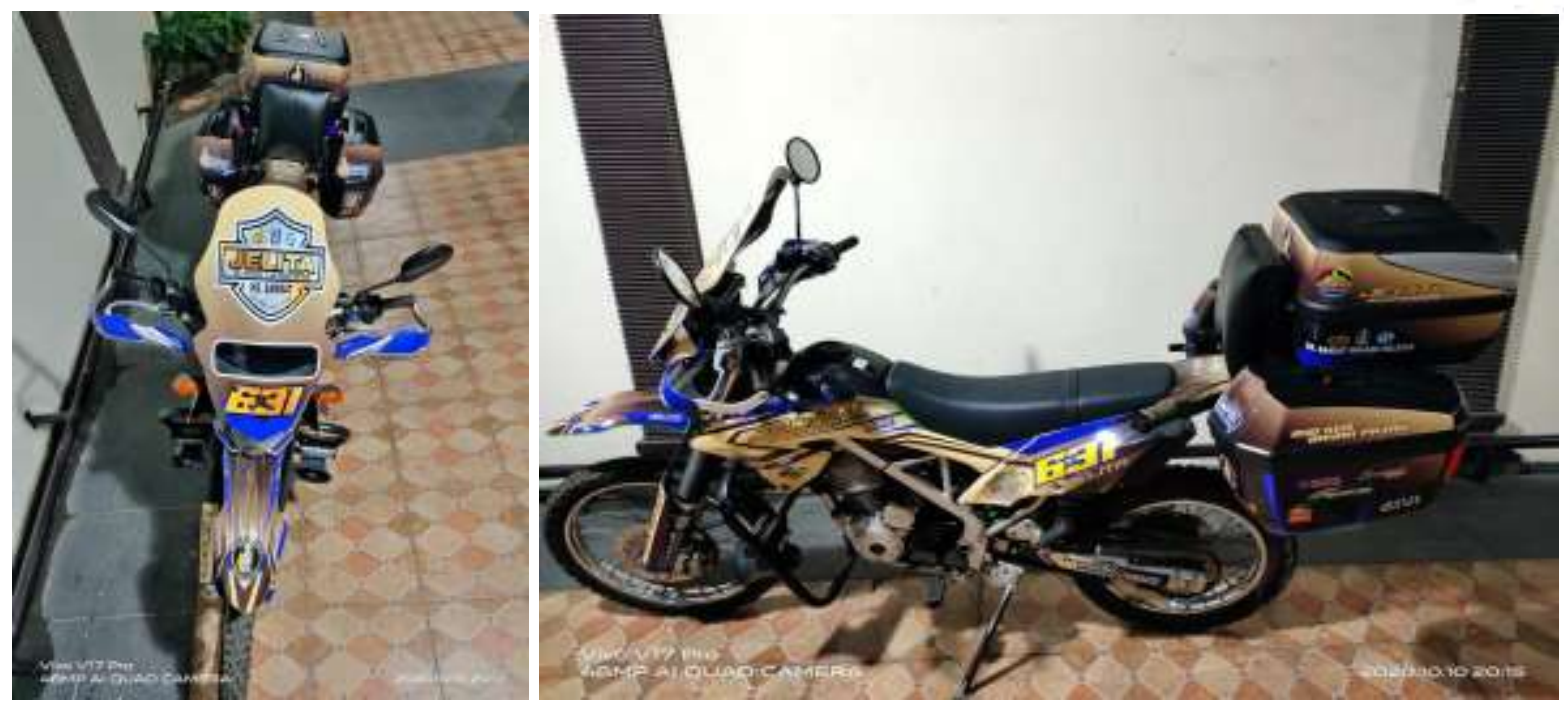

Gambar 3. Motor Trail dan Vasilitas IT Pelayanan JELITA

\section{Faktor Pendukung Program JELITA}

Terdapat sejumlah faktor pendukung terhadap efektifitas program JELITA yang dirancang sebagai bentuk respon positif atas perubahan kebutuhan publik pengguna jasa pelayanan pembayaran pajak pada UPT-PPD, yaitu: (1) ketersediaan sumberdaya manusia yang kompeten; (2) tersedianya sarana dan prasarana yang diperlukan berupa motor trail dengan segala perangkat IT nya; (3) animo publik terhadap program ini relatif bagus, dan bahkan terjadi komunikasi yang konstruktif antara wajib pajak sebagai pengguna pelayanan dan para petugas sebagai perwakilan penyelenggara pelayanan.

\section{Hasil yang Dicapai Melalui Program JELITA}

Tujuan utama program JELITA adalah membantu memenuhi kebutuhan publik akan pelayanan pembayaran pajak yang telah mengalami perubahan, serta membantu publik (terutama yang bertempat tinggal di daerah terpencil, pelosok, dan jauh dari lokasi UPT-PPD Malang Selatan) untuk mengatasi persoalan pembayaran pajak. Hasil lain yang dicapai adalah meningkatnya realisasi penerimaan pembayaran pajak UPT-PPD, terutama pada pajak kendaraan bermotor (PKB) meskipun berada pada masa pandemi Covid-19.

\section{Hal-Hal Yang Diperlukan untuk Pengembangan Inovasi}

Mengingat hasil dari program ini sangat positif, maka perlu didesiminasi ke wilayah desa lain secara massif supaya makin luas jangkauannya, tidak saja di wilayah kerja UPT-PPD Malang Selatan akan tetapi juga di wilayah UPT-PPD lain di Provinsi Jawa Timur. Untuk itulah diperlukan tambahan sumberdaya manusia, tambahan sarana prasarana berupa unit motor trail beserta perangkat IT lengkap. Dan yang tidak kalah pentingnya adalah perlunya assessment untuk kemudian disusun suatu rekomendasi guna melahirkan kebijakan dan melakukan penataan kelembagaan (institutional arrangements) sebagaimana direkomendasikan oleh Bromley. 


\section{KESIMPULAN}

Penelitian ini menghasilkan kesimpulan bahwa inovasi yang berupa layanan Jelajah Lintas Desa (JELITA) yang memberikan layanan baru dengan cara mendekatkan unit pelayanan kepada pengguna layanan yang berada di desa-desa terpencil ternyata mampu menjawab perubahan kebutuhan akan jenis, bentuk dan sifat pelayanan pembayaran pajak yang diperlukan oleh masyarakat. Keberhasilan ini didukung oleh ketersediaan sumberdaya manusia yang kompeten dan sarana-prasarana yang memadai. Hasil inovasi ini adalah peningkatan realisasi pembayaran pajak dan peningkatan kepuasan masyarakat. Pada masa mendatang diperlukan penataan kelembagaan melalui suatu regulasi sedemikian rupa agar inovasi ini implementasinya dapat diperluas ke banyak desa terpencil lainnya, dan untuk itu perlu diterbitkannya kebijakan sebagai panduan, baik pada tataran policy level maupun pada tataran operasional; dengan demikian inovasi pelayanan JELITA ini dapat menjadi entry point lahirnya kebijakan yang responsif, sebagai instrumen untuk melakukan transformasi pelayanan publik di masa pandemi Covid-19.

\section{DAFTAR PUSTAKA}

Anderson, J. E. (1979). Public Policy Making. New York: Holt, Rinehart, and Winston.

Andhika, J. (2020). Dampak Pandemi Covid-19 Bagi Penyelenggaraan Pelayanan Publik. Retrieved from https://ombudsman.go.id/artikel/r/artikel--dampak-pandemi-covid-19-bagipenyelenggaraan-pelayanan-publik

Gubernur Jawa Timur Republik Indonesia. Nomenklatur, Susunan Organisasi, Uraian Tugas Dan Fungsi Serta Tata Kerja Unit Pelaksana Teknis Badan Pendapatan Daerah Provinsi Jawa Timur (2018).

Haryati, E. (2020). Transformasi Tata Kelola Menuju Pemulihan Sektor Pariwisata Pada Masa Pandemi Covid-19: Strategi Kabupaten Banyuwangi dalam Mengkolaborasikan Potensi, Inovasi, dan Aksi. In Merdeka Berpikir - Catatan Harian Pandemi Covid-19 (pp. 121-127). Surabaya: Unitomo Press.

Hidayat, A. A. A. (2010). Metode Penelitian Kesehatan Paradigma Kuantitatif. Surabaya: Health Books Publishing.

Homecare24.id. (2020). Ini Protokol Kesehatan Selama New Normal Agar Terhindar Covid-19. Retrieved from https://medium.com/@homecare24.blog/ini-protokol-kesehatan-selamanew-normal-agar-terhindar-covid-19-bb26df7911a8

Juaningsih, I. N., Consuello, Y., Tarmidzi, A., \& NurIrfan, D. (2020). ptimalisasi Kebijakan Pemerintah dalam penanganan Covid-19 terhadap Masyarakat Indonesia. SALAM Jurnal Sosial Dan Budaya Syar'i, 7(6), 495-508. https://doi.org/10.15408/sjsbs.v7i6.15325

Lumbanraja, A. D. (2020). Urgensi Transformasi Pelayanan Publik melalui E-Government Pada New Normal dan Reformasi Regulasi Birokrasi. Administrative Law \& Governance Journal, $3(2)$.

Menteri Pendayagunaan Aparatur Negara dan Reformasi Birokrasi Republik Indonesia. 
Seminar Nasional Penelitian dan Pengabdian kepada Masyarakat

Universitas Sang Bumi Ruwa Jurai Tahun 2020

Penyesuaian Sistem Kerja Aparatur Sipil Negara Dalam Upaya Pencegahan Penyebaran COVID-19 Di Lingkungan Instasi Pemerintah (2020). Indonesia.

Miles, M., \& Huberman, M. (1992). Analisis Data Kualitatif. (T. R. Rohidi, Trans.). Jakarta: UI Press.

Mulyani, S. (2019). Kebijakan Responsif dan Adaptif Perlu Untuk Menyesuaikan Perubahan. Retrieved from https://www.kemenkeu.go.id/publikasi/berita/kebijakan-responsif-danadaptif-perlu-untuk-menyesuaikan-perubahan/

Pemerintah Republik Indonesia. Pembatasan Sosial Berskala Besar Dalam Rangka Percepatan Penanganan Covid-19 (2020). Indonesia.

Tachjan, H. (2006). Implementasi Kebijakan Publik. Bandung: Truen RTH. 